\title{
4.10. Polarization-interference mapping of biological fluids polycrystalline films in differentiation of weak changes of optical anisotropy
}

\author{
V.O. Ushenko, O.Vanchuliak, M.Yu. Sakhnovskiy, O.V. Dubolazov, \\ P. Grygoryshyn, I.V. Soltys, O.V. Olar, A. Antoniv
}

\subsubsection{Introduction}

Methods of optical diagnostics of biological tissues (BT) include three directions - spectral [1-3], polarization [4-12] and correlation-interference [13-16].

Polarization-interference correlation metrology is generalized for biomedical applications in [17-21].This study presents the possibilities of diagnostics of benign and malignant changes in prostate tissue based on the determination of the coordinate distributions of the magnitude of the complex degree of mutual anisotropy (CDMA) $[18,19]$.

\subsubsection{Materials and methods}

The experimental measurement of CDMA components is based on the approach suggested in [20].

As objects of investigation were selected from optically thin (attenuation coefficient) histological sections of biopsy of benign (adenoma) and malignant (carcinoma) prostate tumors.

Were formed of two groups of patients with the following diagnoses, prepared according to the standard technique on the freezing microtome:

- group 1 - adenoma;

- group 2 - carcinoma. 
Figures 4.10 .1 and 4.10 .2 present the results of polarization-interference mapping of low-frequency (linear birefringence - Fig. 4.10.1) and highfrequency (circular birefringence - Fig. 4.10.2) CDMA distributions of prostate tissue histological sections. Figures consists of the coordinate distributions (fragments (1),(3)) and histograms $N(q)$ (fragments (2),(4)) of sample randomly taken from group 1 (fragments (1),(2)) and from group 2 (fragments (3),(4)).

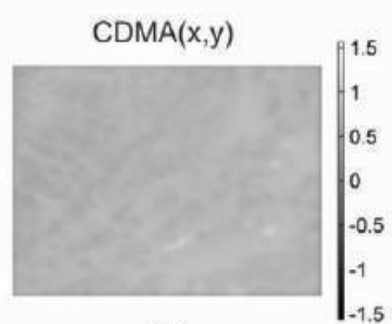

(1)

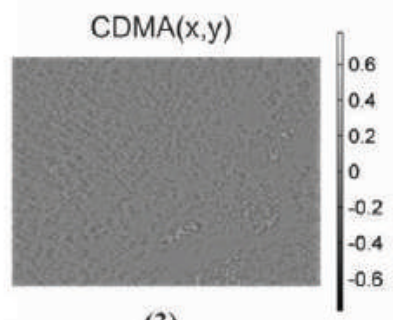

(3)

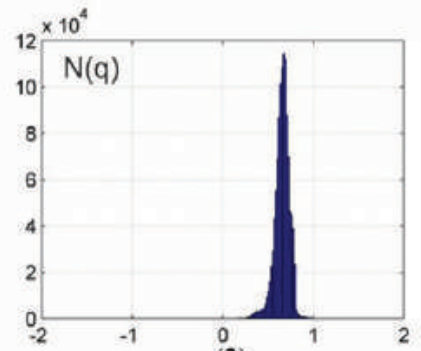

(2)

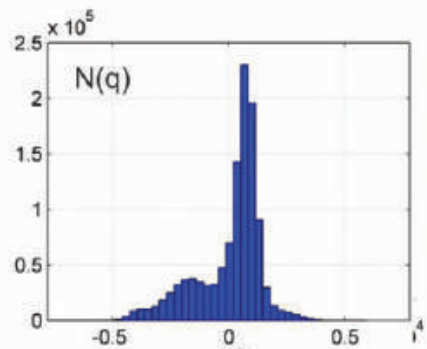

(4)

Fig. 4.10.1. Coordinate structure ((1),(3)) and histograms ((2),(4)) of CDMA distributions of linear birefringence of histological sections of biopsy of prostate tissue of group $1((1),(2))$ and group $2((3),(4))$. 

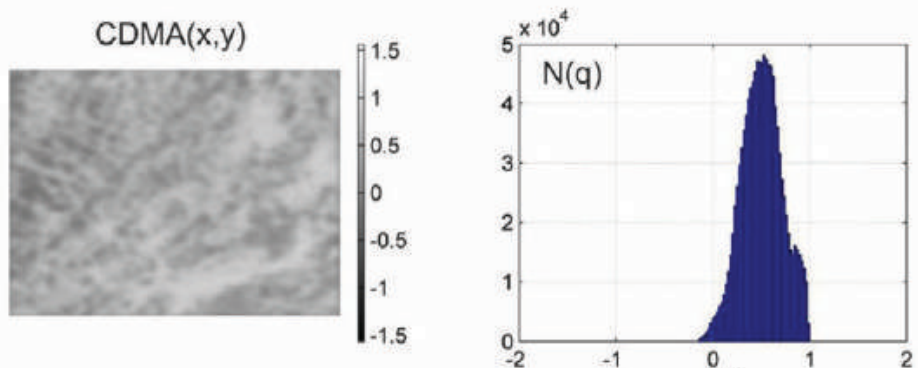

(2)
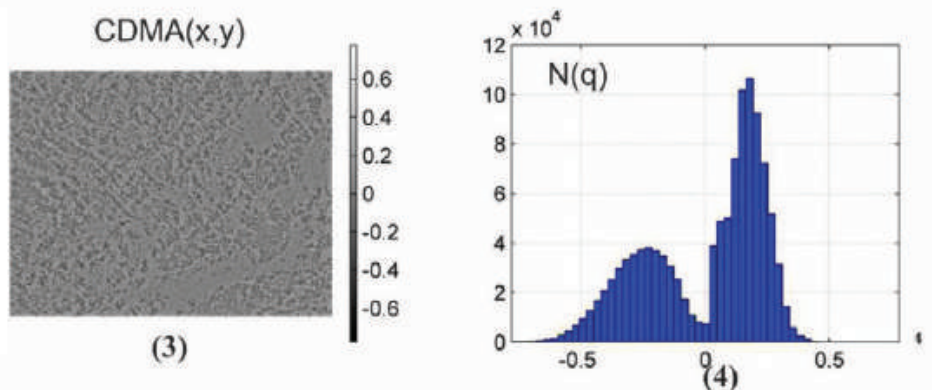

Fig. 4.10.2. Coordinate structure ((1),(3)) and histograms ((2),(4)) of CDMA distributions of circular birefringence of histological sections of biopsy of prostate tissue of group 1 ((1),(2)) and group 2 ((3),(4)).

The differentiation between the group 1 and group 2 was determined by next methods [21-28]. 
Table 4.10.1. Parameters of statistical structure of CDMA coordinate distributions

\begin{tabular}{|c|c|c|c|c|}
\hline \multirow{2}{*}{ Parameters } & \multicolumn{2}{|c|}{$H_{\rho, \omega}$} & \multicolumn{2}{c|}{$H_{\psi}$} \\
\cline { 2 - 5 } & Adenoma & Carcynoma & Adenoma & Carcynoma \\
\hline$M_{1}$ & $0.67 \pm 0.045$ & $0.62 \pm 0.041$ & $0.095 \pm 0.005$ & $0.066 \pm 0.004$ \\
\hline$M_{2}$ & $0.23 \pm 0.013$ & $0.26 \pm 0.018$ & $0.12 \pm 0.006$ & $0.09 \pm 0.007$ \\
\hline$M_{3}$ & $0.43 \pm 0.026$ & $0.23 \pm 0.015$ & $0.77 \pm 0.055$ & $1.28 \pm 0.081$ \\
\hline$M_{4}$ & $0.68 \pm 0.045$ & $0.97 \pm 0.47$ & $1.13 \pm 0.093$ & $1.89 \pm 0.15$ \\
\hline
\end{tabular}

Table 4.10.2 presents operational characteristics of the method of polarization-interference mapping of optical anisotropy of histological sections of biopsy of prostate tissue

Table 4.10.2. Operational characteristics of the method of polarization-interference mapping of optical anisotropy of histological sections of biopsy of prostate tissue

\begin{tabular}{|c|c|c|c|}
\hline Parameters & $M_{i}$ & $H_{\rho, \omega}$ & $H_{\psi}$ \\
\hline \multirow{2}{*}{$A c\left(M_{i}\right)$} & $M_{1}$ & $63 \%$ & $69 \%$ \\
\cline { 2 - 4 } & $M_{2}$ & $68 \%$ & $72 \%$ \\
\cline { 2 - 4 } & $M_{3}$ & $91 \%$ & $88 \%$ \\
\cline { 2 - 4 } & $M_{4}$ & $93 \%$ & $90 \%$ \\
\hline
\end{tabular}

The obtained results enable to state a rather high level of accuracy of azimuthally stable polarization-interference mapping. According to the criteria of probative medicine [26] the parameters $A c(\psi) \sim 90 \%$ correspond to good quality, while $A c(\rho, \omega) \phi 90 \%$ - to high quality. 


\subsubsection{Conclusion}

The comparative investigations of the effectiveness of the developed technique of spatial-frequency Fourier polarimetry of CDMA in the diagnostics of the oncological changes of prostate tissue are carried out.

The criteria of differentiation between the benign (adenoma) and malignant (carcinoma) states of prostate tissue on the basis of the statistical (statistical moments of the $1^{\text {st }}-4^{\text {th }}$ order) analyses of the spatial-frequency filtered distributions of CDMA of protein networks with linear and circular birefringence are determined.

\section{References}

1. V.V. Tuchin, Tissue Optics: Light Scattering Methods and Instruments for Medical Diagnosis, second edition, PM 166, SPIE Press, Bellingham, WA (2007).

2. X. Wang, G. Yao, L. - H. Wang, "Monte Carlo model and singlescattering approximation of polarized light propagation in turbid media containing glucose,” Appl. Opt. 41, 792-801 (2002).

3. X. Wang, L. - H. Wang, "Propagation of polarized light in birefringent turbid media: a Monte Carlo study,” J. Biomed. Opt. 7, 279-290 (2002).

4. Polyanskii, V.K., Angelsky, O.V., Polyanskii, P.V., "Scattering-induced spectral changes as a singular optical effect," Optica Applicata 32 (4), 843$848,(2002)$.

5. Angelsky, O. V., Gorsky, M. P., Hanson, S. G., Lukin, V. P., Mokhun, I. I., Polyanskii, P. V., Ryabiy, P. A., "Optical correlation algorithm for reconstructing phase skeleton of complex optical fields for solving the phase problem,” Opt. Exp. 22(5), 6186-6193 (2014). 
6. Angelsky, O.V., Tomka, Y.Y., Ushenko, A.G., Ushenko, Y.G., Yermolenko, S.B., "2-D tomography of biotissue images in pre-clinic diagnostics of their pre-cancer states," Proc. SPIE., 5972, 158-162, (2005).

7. Yu. A. Ushenko, "Statistical structure of polarization-inhomogeneous images of biotissues with different morphological structures," Ukr. J. Phys. Opt. 6, 63-70 (2005).

8. Angelsky, O., Besaha, R., Mokhun, A., Mokhun, I., Sopin, M., Soskin, M., Vasnetsov, M. "Singularities in vectoral fields ," Proc. SPIE 3904, 40-54 (1999).

9. Angelsky, O. V., Bekshaev, A. Ya., Maksimyak, P. P., Maksimyak, A. P., Hanson, S. G., "Measurement of small light absorption in microparticles by means of optically induced rotation," Optics Express 23(6), 7152-7163 (2015).

10. Angelsky, O. V., Bekshaev, A. Ya., Maksimyak, P. P., Maksimyak, A. P., Hanson, S. G., Zenkova, C. Yu., "Self-action of continuous laser radiation and Pearcey diffraction in a water suspension with light-absorbing particles," Optics Express 22(3), 2267-2277, (2014).

11. Yu. A. Ushenko, T. M. Boychuk, V. T. Bachynsky, O. P. Mincer, "Diagnostics of Structure and Physiological State of Birefringent Biological Tissues: Statistical, Correlation and Topological Approaches" in Handbook of Coherent-Domain Optical Methods, pp. 107-148, Springer Science+Business Media New York (2013).

12. Yu. A. Ushenko, "Investigation of formation and interrelations of polarization singular structure and Mueller-matrix images of biological tissues and diagnostics of their cancer changes," J. Biomed. Opt. 16, 066006 (2011).

13. Angelsky, O. V., Bekshaev, A. Ya., Maksimyak, P. P., Maksimyak, A. P., Hanson, S. G., Zenkova, C. Yu., "Self-diffraction of continuous laser 
radiation in a disperse medium with absorbing particles," Optics Express 21(7), 8922-8938, (2013).

14. E. Wolf, "Unified theory of coherence and polarization of random electromagnetic beams," Phys. Lett. A. 312, 263-267 (2003).

15. J. Tervo, T. Setala, A. Friberg, "Degree of coherence for electromagnetic fields," Opt. Express 11, 1137-1143 (2003).

16. Polyanskii, V.K., Angelsky, O.V., Polyanskii, P. V., "Scattering induced spectral changes as a singular optical effect," Optica Applicata 32, 843-848 (2002).

17. A. G. Ushenko, P. O. Angelsky, M. Sidor, Yu. F. Marchuk, D. R. Andreychuk, and N. V. Pashkovskaya, "Spatial-frequency selection of complex degree of coherence of laser images of blood plasma in diagnostics and differentiation of pathological states of human organism of various nosology," Appl. Opt. 53, B172-B180 (2014).

18. Yu. O. Ushenko, Yu. Ya. Tomka, I. Z. Misevitch, V. V. Istratiy and O. I. Telenga, "Complex degree of mutual anisotropy of biological liquid crystals nets", Opt. Eng. 50, 039001 (2011).

19. Yu. A. Ushenko, Yu. Ya. Tomka and A. V. Dubolazov, "Complex degree of mutual anisotropy of extracellular matrix of biological tissues," Optics and Spectroscopy 110, 814-819 (2011).

20. A. Gerrard, J. M. Burch. Introduction to matrix methods in optics. New York.: A Wiley-Interscience Publication (1975).

21. J. W. Goodman. Statistical properties of laser speckle patters. In: Laser Speckle and Related Phenomena. Ed. J.C. Dainty, pp. 9-75, Berlin: Springer-Verlag (1975).

22. O.V. Angelsky, S.G. Hanson, P.P. Maksimyak, A.P. Maksimyak, C.Yu. Zenkova, P.V. Polyanskii, and D.I. Ivanskyi, "Influence of evanescent wave on birefringent microplates," Opt. Express 25, 2299-2311 (2017). 
23. Angelsky, O. V., Bekshaev, A. Ya., Maksimyak, P. P., Maksimyak, A. P., Hanson, S. G., Kontush, S. M., "Controllable generation and manipulation of micro-bubbles in water with absorptive colloid particles by CW laser radiation," Opt. Express 25, 5232-5243 (2017).

24. Angelsky, P. O., Ushenko, A. G., Dubolazov, A. V., Sidor, M. I., Bodnar, G. B., Koval, G., Trifonyuk, L., "The singular approach for processing polarization-inhomogeneous laser images of blood plasma layers," Journal of Optics, 15(4), 044030 (2013).

25. Dubolazov, A. V., Marchuk, V., Olar, O. I., Bachinskiy, V. T., Vanchuliak, O. Y., Pashkovska, N. V., Kostiuk, S. V., "Multiparameter correlation microscopy of biological fluids polycrystalline networks," In Eleventh International Conference on Correlation Optics, International Society for Optics and Photonics, pp. 90661Y-90661Y (2013).

26. Ushenko, O., Dubolazov, A., Balanets' ka, V., Karachevtsev, A., Sydor, M., "Wavelet analysis for polarization inhomogeneous laser images of blood plasma," Proc. SPIE. Vol. 8338 (2011).

27. Ushenko, V. A., O. V. Dubolazov, A. O. Karachevtsev, "Two wavelength Mueller matrix reconstruction of blood plasma films polycrystalline structure in diagnostics of breast cancer," Applied optics 53(10), B128-B139 (2014).

28. A. Petrie, B. Sabin, [Medical Statistics at a Glance], Blackwell Publishing (2005). 